\title{
Buildings Fraught with Meaning: An Introduction to a Special Issue on Synagogue Architecture in Context
}

\author{
LEE SHAI WEISSBACH \\ University of Louisville, Louisville, KY, USA \\ E-mail:weissbach@louisville.edu
}

It has frequently been observed that synagogue buildings have long fulfilled three related but somewhat different functions, as reflected in the three Hebrew terms used to designate these buildings. The synagogue customarily has been called a beit knesset, a house of assembly; a beit tefilah, a house of prayer; and also a beit midrash, a house of study. ${ }^{1}$ However, there is yet another function of a synagogue building at least as significant as the three usually enumerated, for a synagogue is also a mivneh simli, a symbolic structure fraught with meaning. That is, a synagogue building often acts as a concrete representation of the character and condition of the Jewish community it serves. It can and often does reveal not only who the Jews who make use of it are and how they behave, but also what they think and what they believe. As one synagogue architect put it recently, "architecture speaks. It expresses what we value from the past, what our needs are now, and, at its best moments, looks to the future." ${ }^{2}$ As much as synagogue buildings provide venues for worship, study, and assembly, they also reflect the circumstances and the mentalité of those who build and use them.

The symbolic power of synagogue buildings has long been recognized in Jewish tradition. This is why, as a mark of both its sanctity and its central role in Jewish communal life, the synagogue was to be, at least ideally, the tallest building in a city; tractate Shabbat of the Babylonian Talmud warns that any city in which other roofs are higher than that of the synagogue is destined to be destroyed. A recognition of the symbolic standing of synagogues is also why, from the earliest times, there have been rules governing how one is to behave where these buildings are concerned. The Talmud teaches that a synagogue building must not be used as a pedestrian short-cut, for example, and that even the ruins of synagogues must be treated with respect. The sixteenthcentury Shulchan Aruch decrees that, generally speaking, one should not behave in a frivolous manner in a synagogue, that one should not eat or drink within the sanctuary, nor use it as a refuge from the elements.

More specifically, symbolism has also figured in certain matters of synagogue design. Traditionally, synagogues in Europe and the Americas have 
been orientated toward the east, that is, toward Jerusalem, signifying the connection of the Jewish people with the Land of Israel and their longing for an end of exile. So, too, there has been a requirement that synagogues be designed with windows. According to the Shulchan Aruch, these were expected to be twelve in number, corresponding to the twelve tribes of Israel, "each with its own window to heaven, so to speak," in the words of one authority. According to Abraham Isaac Kook, the renowned Ashkenazic chief rabbi of Palestine under the British Mandate, synagogue windows were to serve as reminders that during prayer, worshipers should be aware of the outside world. ${ }^{3}$

The placement of the bimah in the center of the worship hall, as has been traditional in Ashkenazic synagogues, or across the worship space from the aron kodesh, as is the custom in most Sephardic and traditional Italian synagogues, with worshipers arrayed around the raised platform, has not only practical acoustic value, but also symbolic meaning. These arrangements place emphasis on the actual reading of the Torah, more than on the physical Torah scrolls in the ark; they also highlight the role of the officient as a shaliach tzibur, a representative of the community; and they promote group cohesion. ${ }^{4}$

When it comes to the exterior style and shape of synagogue buildings, the rules have never been hard and fast. Nonetheless, as early as the eighteenth century, at least one authoritative rabbi recognized that there was a lot to be read into the overall appearance of a synagogue building. In a 1787 responsum addressed to the Jews of Trieste, Rabbi Ezekiel Landau of Prague declared that there was no prohibition against constructing a synagogue in an octagonal or other unusual shape, but at the same time he warned against the temptation to copy the architectural styles of the gentile elite. Rabbi Landau felt that ostentatious displays of Jewish wealth would be unseemly for a people in exile and he feared that elaborate synagogue buildings might signify a growing assimilation. In order to bolster his position, he quoted a verse from the prophet Hosea: "For Israel has forgotten his Maker, and built palaces" (Hosea 8:14). Landau advised that, when it came to synagogue design, it was better "not to change any of the old customs.".

By the nineteenth century, as Jewish emancipation spread and as Jewish communities encountered fewer and fewer restrictions on how they could construct their synagogues, at least in Western societies, the question of the symbolic significance of various building styles continued to arise in the minds of synagogue architects and community leaders. In the mid nineteenth century, for example, the German Jewish architect Albert Rosengarten argued that the Egyptian motifs that had been used in some earlier synagogues were inappropriate, since (as one commentator has put it) "the association between Jews and Egyptians had not been all that happy in the past." By contrast, at 
about the same time, when the so-called Moorish style came into vogue in synagogue architecture, first in Europe and then in America, this was seen in a more positive light, resulting as it did from a desire to associate Jews with a romantically idealized vision of the Orient, where Judaism had originated. ${ }^{6}$

Of course, modern architects and modern observers of synagogue design have become even more cognizant of the symbolic aspects of synagogue architecture. Scholars in the field have often acknowledged that synagogue buildings not only fulfill several practical functions, but also reveal a great deal about the nature of the communities they serve. These buildings derive much of their meaning from the way they reflect the Jewish experience more generally. In her seminal work on American synagogue architecture, Rachel Wischnitzer, for example, made the point that some synagogues looked the way they did because "a style was to be chosen for its associational qualities" and she observed that the synagogue buildings erected in the U.S. reflected, among other things, "the diversity of the [American Jewish] immigrants' origins and outlooks, the effect of time as a factor devitalizing transplanted traditions, and, above all, the impact of new ideas and concepts upon the attitudes of the community as a whole." Along the same lines, when Carol Krinsky analyzed the synagogues of Europe, she interrogated not only "architecture" and "history," but also "meaning," as the subtitle of her wide-ranging survey attests. $^{7}$

David Kaufman, too, in exploring the development of multi-purpose "synagogue-centers" in America, has demonstrated how these buildings signified a whole new approach to Jewish life in the country, as American Jewry grappled with the question of how to attract Jews to communal life when affiliation was a totally voluntary matter, and how to resolve the tension between a secular Jewish social identity and a Jewish religious identity. ${ }^{8}$ And, to take one final example, in her study of the Jewish houses of worship of nineteenth and twentieth century Cairo, Hana Taragan of Tel Aviv University has concluded that "these are synagogues whose architectural styles attest to the history of the local Jews and faithfully reflect their number, group affiliation, and economic status." 9

The symbolism and evocative imagery inherent in synagogue architecture have gotten ample notice in discussions aimed at a more general audience, as well. A recent article in the Wall Street Journal covering the inauguration of a visitors' center at the Beth Sholom synagogue designed by Frank Lloyd Wright in Elkins Park, Pennsylvania, points out that "the building, unusual in both form and materials, radiates otherworldliness. Symbolizing Mount Sinai, and evoking a vast desert tent, the hexagonal structure towers above the leafy avenue." The dramatic sloped interior, the article continues, "seems to obliterate the distinction between heaven and earth." Indeed, Mortimer J. Cohen, the rabbi at Beth Sholom who first contacted Wright about designing 
the congregation's building in 1953, had himself been concerned with symbolism from the outset. He had asked the architect specifically for "a "new thing' - the American spirit wedded to the ancient spirit of Israel." 10

Similarly, a recent congregational newsletter describing another Beth Shalom synagogue, this one in San Francisco, designed by the prominent architect Stanley Saitowitz and completed in 2008, notes that the sanctuary was planned without a balcony (that feature "being the last vestige of the $m e$ chitza"), that the worship space has a central bimah surrounded on two sides by the congregation (thus maintaining a sense of "intimacy"), and that "from the outside, the windowless concrete skin covering the exterior of the ark recalls the Western Wall in Jerusalem." In other words, the newsletter makes clear that the design of the synagogue is heavily laden with symbolism. Beth Shalom's new building is intended, among other things, to convey the congregation's egalitarianism, its quest for family-like closeness, and its ties to the Land of Israel. ${ }^{11}$

Perhaps the most explicit recent exposition of symbolism in synagogue architecture comes from the Internet site of the Reconstructionist Adat Shalom congregation in Bethesda, Maryland. It is worth quoting at length. At the synagogue,

...the path from the everyday world into the sacred begins in the parking lot. The gravel of the parking lot symbolizes the journey through the desert; the cedars around the forecourt represent those that Solomon used to build his temple. The passage over water in front of the building may represent crossing the Jordan into the Promised Land, or the ritual cleansing necessary before entering the Temple in Jerusalem.

The sanctuary's striking canvas ceiling "wraps the entire congregation in a tallit"-or, more literally, recalls the desert tents of the Jewish ancestors. Like the tents of Abraham and Sarah, this "tent" has open sides (the windows below) as a sign of hospitality and openness. The Jerusalem stone surrounding the ark provides a connection to Israel and is a symbol of the Western Wall... Stripes on the carpet are oriented toward Jerusalem. ${ }^{12}$

The essays presented in this special issue reinforce the notion that in order fully to appreciate the significance of synagogue buildings in early modern and modern Jewish society, one must understand these buildings not only as places of worship, study, and assembly, but also as repositories of symbolic meaning. At the same time, the essays offer important new information about synagogue architecture in the Atlantic World of the seventeenth and eighteenth centuries, in nineteenth-century Amsterdam, in America at the turn of the twentieth century, and in Poland in the decades prior to World War II. 
Laura Leibman's article, focusing on the design of Rhode Island's Touro synagogue, which the Forward recently called "arguably the most important Jewish historic site in America," ${ }^{13}$ is all about symbolic underpinnings. Leibman contends that while previous scholars have recognized the connections between Sephardic synagogues such as those in Amsterdam, London, and Newport, they have misinterpreted the common origins of the features of design they share. What was involved here was not simply a matter of newer buildings borrowing ideas from older buildings and from pattern books, nor was it a matter of relying on Christian sources. Leibman demonstrates that the prominent seventeenth and eighteenth century synagogues of Amsterdam, London, and the Dutch and English colonies across the Atlantic, as well as many of Christopher Wren's churches, all drew their inspiration from Solomon's ancient Temple in Jerusalem as it was described by the Dutch rabbi Jacob Judah Leon de Templo. All these synagogues, she contends, were built in conformity with a neo-Solomonic order that "carried with it a specific symbolism." Among other things, "the use of the neo-Solomonic order in the Dutch and English colonies physically reflected Menasseh ben Israel's conviction that the building of synagogues in the New World predicted the arrival of the Messiah and the erection of the Third Temple."

Saskia Coenen Snyder's article, on the other hand, serves as a useful reminder that, in looking for the underlying meanings of buildings, or of other aspects of a society's material culture, the absence of certain elements can be as informative as their presence. Her article suggests that a lack of attention to prominent display and outward grandeur in the creation of synagogues in nineteenth-century Amsterdam was itself reflective of larger truths about the Jewish community. Snyder argues that the absence of new monumental synagogues in Amsterdam in the latter part of the nineteenth century echoed the priorities of the contemporary Dutch Jewish community, which was more concerned with expenditures made for communal and individual welfare than with synagogue construction and, thus, was content to erect modest houses of prayer to meet immediate needs rather than to build impressive houses of worship that might signify Amsterdam Jewry's comfortable position within Dutch society and possibly aid to advance its integration into the community of Dutch citizens. Recognizing that in many other European cities, "nineteenth-century synagogues... became visual expressions of how Jews saw themselves and how they wanted to be seen by their contemporaries-as confident bourgeois citizens whose faith in emancipation and sense of security permitted the public celebration of Judaism," Snyder contends that such buildings were viewed as unnecessary in the Dutch context.

Samuel Gruber's article takes us back to North America and forward to the turn of the twentieth century. His article concerns the flowering of neo- 
classical design in American synagogue architecture at the end of the nineteenth century and in the early years of the twentieth and calls attention to the role in this development played by Arnold Brunner, the most prominent Jewish synagogue architect of his time. Gruber ties the adoption of neoclassical forms in the construction of synagogues to architectural trends in other realms and, again, shows how the use of particular styles reveals much about the orientation and ideology of at least some segments of the American Jewish community.

Eleanora Bergman's article on Polish synagogues of the early twentieth century, the fourth article in this collection, not only acquaints us with the appearance of synagogues in the $d w o r e k$, or manor house, style, but does so against the background of the Polish nationalistic historic preservation movement of the period and discusses the relationship of that movement to Polish Jewish monuments. Bergman's article also introduces Henryk Stifelman, perhaps the most important Jewish architect in Poland in the early decades of the twentieth century and a leading advocate of the manor house tradition.

Interestingly, at least three of the four articles in this collection touch on the manner in which synagogue architects related to the "national" architectural styles of their respective countries. A concern with national style is most obvious in the article by Gruber, which shows that the neoclassical design of so many synagogues around the turn of the twentieth century was associated both with American patriotism and with urban beautification, and in the article by Bergman, which demonstrates how synagogues in the manor house style conformed to the militantly nationalistic approach to architecture that emerged in Poland in the early decades of the twentieth century. But the concept of a national style surfaces, as well, in Synder's article, as she informs us that even the mundane prayer houses of nineteenth-century Amsterdam had touches of traditional Dutch design (in the use of typical Dutch gables, for instance), and that Emanuel Rood, the architect of the only freestanding synagogue constructed in Amsterdam during the nineteenth century, designed his building in the Dutch Renaissance mode because he considered it to be his country's national style. In his mind, it made sense for the Jewish community to associate itself with the architectural nationalism of the period. Even Leibman's article hints at considerations of a style common to many English environments by noting the connections between Christopher Wren's London churches and the synagogue buildings of London and the English colonies.

Of course, the members of congregations that commissioned synagogues in times past may not have been terribly concerned with the choice of an architectural style. Indeed, Saskia Snyder points out specifically that matters of style were not of prime concern in nineteenth-century Amsterdam. Nonetheless, synagogues in a "national style" would not have been constructed if their 
congregations had disapproved of its use. Thus, there is clearly meaning to be derived from the appearance of synagogues that reflected the dominant design trends in their countries. The selection of national styles by architects, and their acceptance by Jewish congregations, provides a concrete illustration of the way in which at least some Jews in some countries were making an effort to identify with their homelands, whether out of self-confidence, pride, and a genuine sense of allegiance, or in order to refute any lingering suspicions that they were aliens even within their own countries.

Just as important as the influence of national styles on synagogue design in recent centuries, however, has been the influence of particularistic Jewish concerns. As each of the articles in this collection demonstrates, even those who were erecting synagogue buildings designed to fit seamlessly into the local architectural environment did not loose sight of the specifically Jewish identities of the congregations for which they were building. This was obviously the case where the model for seventeenth and eighteenth century synagogues was Solomon's Temple, with its implications for the anticipation of a messianic age and an end of exile, but elsewhere also, particularly Jewish precedents were evoked. As Samuel Gruber shows, Arnold Brunner justified the erection of neo-classical synagogues in America not only on the basis of the adoption of neoclassicism as an American style, but also on the basis of the discovery of Greco-Roman synagogue remains in the Land of Israel. Similarly, the designers of Polish synagogues in the interwar period used as one of their models the wooden synagogues of earlier times, buildings which, Eleanora Bergman informs us, "did not look foreign" but were nonetheless "clearly distinguishable from other structures" and thus distinctively Jewish. Of course, where the synagogue buildings being erected were intended to serve Orthodox congregations, the layout of their interiors had to conform to particularly Jewish precedents, whatever their exterior appearance. In the end, the synagogue buildings discussed in this collection of essays all reflect the tension present in so many Jewish communities between a tendency to acculturate and a tendency to remain a people apart.

Finally, it is worth observing that all four of the articles in this special issue relate to some of the most novel recent developments in the scholarship of Jewish Studies, and, in particular, to the current engagement with the topic of "Jewish art." This includes the question of whether Jews have an artistic tradition at all. Several scholars, including Kalman Bland and Margaret Olin, have recently produced important studies investigating why, as Bland put it, "Jewish aniconism, the denial of Jewish art, became the conventional wisdom in modern secular scholarship" and debunking the idea that Jews could not create art, or at least not visual art. In doing so, these scholars have called attention to the abundant artistic creations fashioned by Jews over the centuries. ${ }^{14}$ In this connection, all the articles in this special issue support 
the assertion that Jews have long been active in the realm of art. After all, the design and construction of a synagogue building is often an artistic endeavor in and of itself, and what goes on within a synagogue is to a large extent a "performance" with artistic implications. As the early twentieth-century German-Jewish philosopher Franz Rosenzweig recognized, Jewish worship is a total experience and there is great importance in the "sensory, sensual, architectural, and theatrical aspects of Jewish observance." 15

Moreover, because all four of the articles presented here interrogate the meaning of structures that individuals encounter primary with the sense of sight, they might all be thought of as contributions to what has been called the field of Visual Culture, or "the new, new art history," which, while maintaining an interest in understanding art in its larger social, cultural, and intellectual context, advocates an emphasis on the use of all aspects of the visual world as a window into society. The articles here all remind us that, as Barbara Stafford, a pioneer in the field, has suggested, "the seen world... is a vibrant source of information, ranking with and often surpassing the semiotic as a source of knowledge about a given time and place." 16

With all the attention now being given to artistic endeavor in its wider context and to the broader world of the visual, recent students of art have sometimes been accused of "studying everything but 'the work of art itself'."17 The authors of the articles in this collection, however, have not lost sight of the actual architectural creations about which they are writing. Although they may be concerned primarily with what we can learn about the Jewish experience in times past by studying synagogue buildings, they have not ignored the buildings themselves. Indeed, in the following pages, they introduce us or, in some cases, reintroduce us to significant structures such as Peter Harrison's 1764 Touro Synagogue in Newport, Rhode Island; Emanuel Rood's 1891 Gerard Dou Synagogue in Amsterdam; Arnold Brunner's 1897 Shearith Israel in New York City; and Henryk Stifelman's 1916 synagogue in Ostrołęka, Poland, and they provide detailed descriptions (and often illustrations) of these synagogues and others. Thus, as much as we can come to understand the circumstances under which these buildings were erected and the history of their reception and their influence, we can come also to appreciate these structures as works of art themselves.

Just as the articles in this collection relate to the recent focus on Jewish art, so too do they relate to what has been called the "spatial turn" in Jewish historiography. After emphasizing for so long the ways in which Judaism has transcended specific locations to maintain translocal and transnational connections, scholars are now paying increased attention to the importance of specific settings and environments for an understanding of the Jewish experience, be these places East European shtetls, pilgrimage sites in the Land of Israel, or Jewish summer camps, to give but a few examples. Generally speaking, "Jewish spaces" have been understood as "spatial environments in which 
Jewish things happen, where Jewish activities are performed, and which in turn are shaped and defined by those Jewish activities." Thus, the essays presented here, concentrating as they do on the significance of buildings for an understanding of Jewish history and identity, all relate to this new historiographic trend. ${ }^{18}$ Indeed, one might say that the synagogue is the archetypical Jewish space in any locale, the central "place" associated with Jews. At least in Diaspora settings, it is the clearest indication that a Jewish community is a component of the local society. As the historian Jack Wertheimer has said in speaking of the United States, synagogues are "the oldest, hardiest and most participatory institutions maintained by Jews." The art historian Joseph Gutmann has made an even more sweeping statement, proclaiming that "the synagogue has been the most important Jewish institution for the last two thousand years." ${ }^{19}$ Certainly, synagogue buildings belong in any discussion of the role of "place" in Jewish history.

Ultimately, the essays presented in this special issue remind us of the tremendous value of studying any group's material culture as a source for understanding its history and identity. In their search to uncover the past, historians are constantly on the lookout for all sorts of clues, and every item of evidence uncovered can be put to any number of uses. Some pieces of evidence may provide new information that is unavailable otherwise, while others can serve to confirm and perhaps add nuance to what has already been discovered. Yet other pieces of evidence can be used simply to illustrate something that is already well understood and needs no further "proof" per se. The articles in this special issue clearly demonstrate that buildings, and in this case specifically synagogue buildings, can be both extremely interesting and very valuable sources of evidence for the study of the Jewish experience in recent centuries. These articles all demonstrate that synagogue buildings can be appreciated and interpreted in a number of ways and that when it comes to synagogue architecture, the observer benefits from reflecting on the broader meanings of what the eye sees. As the landscape historian John Stilgoe has observed, "a little acute observation... opens up larger issues that invigorate the mind, that entice understanding, that flex mental muscle, [and] that fit the explorer for further exploring." 20

\section{Notes}

1. See, for example, David Bridger and Samuel Wolk, eds., The New Jewish Encyclopedia (West Orange, N.J.: Berman House, 1976), 469; Recent American Synagogue Architecture [exhibition catalogue] (New York: The Jewish Museum, 1963), 11; Mark Zborowski and Elizabeth Herzog, Life is with People: the Jewish Little Town of Eastern Europe (New York: International Universities Press, 1952), 49; David Kaufman, Shul with a Pool: The "Synagogue-Center" in American Jewish History (Hanover, N.H.: Brandeis University 
Press, 1999), esp. 5-6; Joseph Gutmann, The Jewish Sanctuary (Leiden: E.J. Brill, 1983), i; Samuel C. Heilman, Synagogue Life: A Study in Symbolic Interaction (Chicago: University of Chicago Press, 1976), which includes chapters titled "The House of Prayer," "The House of Study," and "The House of Assembly"; and even Benjamin Blech, The Complete Idiot's Guide to Jewish History and Culture, 2nd ed. (New York: Alpha Books, 2004), 99.

2. Maurice N. Finegold, "Synagogue Architecture: Change and Continuity," United Synagogue Review (Spring, 2005): 35.

3. On traditional rules concerning the synagogue building and its design, see, for example, Louis Jacobs, The Jewish Religion: A Companion (New York: Oxford University Press, 1995), 513-515 (quotation from p. 513); Abraham Millgram, Jewish Worship (Philadelphia: Jewish Publication Society, 1971), 336-337; Yosseph Shilhav, "Principles for the Location of Synagogues: Symbolism and Functionalism in a Spatial Context," Professional Geographer 35:3 (1983): 324-329; and The Jewish Encyclopedia, s.v. "Synagogue."

4. On the placement of the bimah, see, for example, Carol Herselle Krinsky, Synagogues of Europe: Architecture, History, Meaning (Cambridge, Mass.: MIT Press, 1985), 22; Finegold, "Synagogue Architecture"; and Lee Shai Weissbach, "The Architecture of the Bimah in American Synagogues: Framing the Ritual," American Jewish History 91 (March, 2003).

5. See Jacobs, The Jewish Religion, 513.

6. See, for example, Helen Rosenau, "Gottfried Semper and German Synagogue Architecture," Leo Baeck Institute Year Book 22 (1977): 237-244 (quotation from p. 238); and Ivan Davidson Kalmar, "Moorish Style: Orientalism, the Jews, and Synagogue Architecture," Jewish Social Studies, new series, 7:3 (Spring/Summer, 2001): 68-100.

7. Rachel Wischnitzer, Synagogue Architecture in the United States (Philadelphia: Jewish Publication Society, 1955), quotations from pp. 7, 4; Krinsky, Synagogues of Europe.

8. David Kaufman, Shul with a Pool: The "Synagogue-Center" in American Jewish History (Hanover, N.H.: Brandeis University Press, 1999).

9. Hana Taragan, "The 'Gate of Heaven' (Sha'ar Hashamayim) Synagogue in Cairo (18981905): On the Contextualization of Jewish Communal Architecture," Journal of Jewish Identities 2 (2009): 33.

10. Julia M. Klein, "The Rabbi and Frank Lloyd Wright," Wall Street Journal, Dec. 22, 2009.

11. See "Welcome Home: A Synagogue of Our Own," Haruach [congregational newsletter] 7:1 (May, 2008), 6. See also "Congregation Beth Sholom Synagogue" at http://archrecord. construction.com/projects/portfolio/archives/0808bethsholom-1.asp (accessed March 21, 2010).

12. Laura Hartman, "Constructing Reconstructionism: Religious Values Expressed in Architecture at Adat Shalom Reconstructionist Synagogue in Bethesda, Maryland" at http://www.adatshalom.net/constructing.html (accessed Dec. 30, 2009).

13. Anthony Weiss, "Touro Struggles with its Historic Legacy," Forward, June 5, 2009.

14. See Kalman P. Bland, The Artless Jew: Medieval and Modern Affirmations and Denials of the Visual (Princeton, N.J.: Princeton University Press, 2000); and Margaret Rose Olin, The Nation without Art: Examining Modern Discourses on Jewish Art (Lincoln, Neb.: University of Nebraska Press, 2001). See also Daniel Morris, "Reimagining the "Artless Jew': A Commentary on Recent Interventions in Jewish Art History," Shofar 24:2 (Winter, 2006). The quotation here is from Bland, Artless Jew, 13.

15. See Barbara Kirshenblatt-Gimblett and Jonathan Karp, "Introduction" in The Art of Being Jewish in Modern Times, Barbara Kirshenblatt-Gimblett and Jonathan Karp, eds. (Philadelphia: University of Pennsylvania Press, 2007), 9. 
16. See, for example, Marsha Meskimmon, "Visuality: The new, new art history?," Art History 20:2 (June 1997); and William Innes Homer, "Visual Culture: A New Paradigm," American Art 12:1 (Spring, 1998). The quotation here is from Homer, "Visual Culture," 8.

17. See Kirshenblatt-Gimblett and Karp, "Introduction," 14.

18. On the spatial turn in Jewish Studies, see, for example, Julia Brauch, Anna Lipphardt, Alexandra Nocke, eds., Jewish Topographies: Visions of Space, Traditions of Place (Aldershot, Eng.: Ashgate Publishing, 2008); and Charlotte Elisheva Fonrobert, "The New Spatial Turn in Jewish Studies" AJS Review 33:1 (April, 2009). On the spatial turn in the social sciences and humanities more generally, see, for example, Barney Warf and Santa Arias, eds., The Spatial Turn: Interdisciplinary Perspectives (New York: Routledge, 2008). The quotation here is from Brauch, Lipphardt, and Nocke, eds, Jewish Topographies, 4.

19. See Jack Wertheimer, "Preface" in Jack Wertheimer, ed., The American Synagogue: A Sanctuary Transformed (Cambridge, Eng.: Cambridge University Press, 1987), vii; and Gutmann, Jewish Sanctuary, i.

20. John Stilgoe, Outside Lies Magic (New York: Walker and Co., 1998), 17-18. 